\title{
2019 Ejtm Special on Muscle Fascia
}

\author{
Carla Stecco, Raffaele De Caro
}

Department of Neurosciences, Section of Human Anatomy, University of Padova, Padova, Italy

This article is distributed under the terms of the Creative Commons Attribution Noncommercial License (CC BY-NC 4.0) which permits any noncommercial use, distribution, and reproduction in any medium, provided the original author(s) and source are credited.

\begin{abstract}
For many years the fasciae have been considered by the anatomists only as a "white envelope for the muscles", that is generally removed in anatomical tables, to recognize muscle nerves and vessels. This is one of the reasons that different descriptions of the fasciae exist. On the other hand, in the last years the fasciae and their properties are becoming of central importance to clinicians practicing in various conventional and alternative therapies. The results from the worldwide research activities constitute a body of significant and important data, but this clinical interest is not supported by in-depth comprehension to how integrate the new knowledge about fasciae with the classical biomechanical models based on muscles, tendons and bones. To close this gap an Ejtm Special on "Muscle Fascia" will be published September 30, 2019, but the typescripts will be added to the Ejtm Early Release list as soon as all authors will approve their Epub papers. Deadline for original articles and reviews is June 1st, 2019, but the Editors hope that authors submit their typescripts much earlier.
\end{abstract}

Key Words: fascia, connective tissue, epimysium, proprioception, motor coordination Eur J Transl Myol 29 (1): 1-3, 2019

For many years the fasciae have been considered by the anatomists only as a "white envelope for the muscles", and little attention has been given to their macroscopic and histological anatomy. In anatomic displays the fascia is generally removed, so the viewer can see nerves and vessels but fails to appreciate the fascia which connects, and separates, these structures. It is probably for this reason that different descriptions of the fasciae exist in literature. ${ }^{1-2}$ In contrast to this, in the last years the fasciae and their properties are becoming of central importance to clinicians practicing in various conventional and alternative therapies and the fascial tissue is actually the subject of a wide range of scientific research with many specializations. The results from the worldwide research activities constitute a body of significant and important data, but this clinical interest is not supported by in-depth comprehension to how integrate the new knowledge about fasciae with the classical biomechanical model based on muscles, tendons and bones.

Thus, the aim of the "2019 Ejtm Special on Muscle Fascia”, Carla Stecco and Raffaele De Caro Guest Editors, is to point attention to several open questions: $\checkmark$ Do fasciae have a role in pain perception? ?-5 $^{3-5}$

$\checkmark$ How fasciae and muscles interact during movement? Have the fascia a role in posture ${ }^{6}$

$\checkmark$ How do the various fasciae appear under ultrasound, MRI, and CAT scans? Could these instruments help us to understand the structure of the fasciae in living people? And what about the relationship between fasciae and surrounding structures? ${ }^{7-10}$

$\checkmark$ What is the role of the extracellular matrix, and in particular of the hyaluronic acid component? ${ }^{11}$

$\checkmark$ Could fasciae be considered elastic tissue? What is the percentage of elastic fibres within fasciae? Are there regional variations? ? $^{12}$

$\checkmark$ Are fasciae innervated? What type of receptors could be recognized within fasciae? Can fascia play a role in proprioception ${ }^{13-15}$

$\checkmark$ Do the fasciae possess a basal tonus? Have they the capacity to actively contract? ${ }^{16}$

$\checkmark$ Do fasciae have a role in motor coordination ${ }^{17}$

Answers to these questions will add to the many tools of mobility and pain rehabilitation strategies, ${ }^{18-30}$ contributing to clinician's understanding of the 
biomechanical behavior of the fasciae, of their role in acute and chronic myofascial pain syndromes and of the effectiveness of different therapies.

\section{Acknowledgments}

Funding: None

\section{Conflict of Interest}

The author declares to have none conflict of interests.

\section{Ethical Publication Statement}

Author confirms that he has read the Journal's position on issues involved in ethical publication and affirms that this report is consistent with those guidelines.

\section{Corresponding Author}

Carla Stecco, Department of Neurosciences, Section of Human Anatomy, University of Padova, Padova, Italy. E-mail: carla.stecco@unipd.it

Email of Coauthor: raffaele.decaro@unipd.it

\section{References}

1. Schleip R Jäger H, Klingler W. What is 'fascia'? A review of different terminologies. J Bodyw Mov Ther 2012;16:496-502. doi: 10.1016/j.jbmt.2012. 08.001. Epub 2012 Aug 22. Review.

2. Adstrum S. Fascial eponyms may help elucidate terminological and nomenclatural development. J Bodyw Mov Ther 2014;19:516-25. doi: 10.1016/j.jbmt.2015.04.002. Epub 2015 Apr 21.

3. Langevin HM, Fox JR, Koptiuch C, et al. Reduced thoracolumbar fascia shear strain in human chronic low back pain. BMC Musculoskelet Disord 2011;12:203. doi: 10.1186/1471-2474-12-203.

4. Taguchi T, Yasui M, Kubo A, et al. Nociception originating from the crural fascia in rats. Pain 2013;154:1103-14. doi: 10.1016/j.pain.2013.03. 017.

5. Schilder A, Magerl W, Hoheisel U, et al. Electrical high-frequency stimulation of the human thoracolumbar fascia evokes long-term potentiation-like pain amplification. Pain 2016; 157:2309-17. doi: 10.1097/j.pain.000000000 0000649.

6. Wilke J, Schleip R, Yucesoy CA, Banzer W. Not merely a protective packing organ? A review of fascia and its force transmission capacity. J Appl Physiol 2018;124: 234-244. doi: 10.1152/jappl physiol.00565.2017. Epub 2017 Nov 9.

7. Carraro U, Edmunds KJ, Gargiulo P. 3D False Color Computed Tomography for Diagnosis and Follow-Up of Permanent Denervated Human Muscles Submitted to Home-Based Functional Electrical Stimulation. Eur J Transl Myol 2015 Mar 17;25(2):5133. doi: 10.4081/ejtm.2015.5133.

8. Edmunds KJ, Gíslason MK, Arnadottir ID, et al. Quantitative Computed Tomography and Image
Analysis for Advanced Muscle Assessment. Eur J Transl Myol 2016;26:6015. doi: 10.4081/ ejtm.2016.6015. eCollection 2016 Jun 13.

9. Edmunds K, Gíslason M, Sigurðsson S, et al. Advanced quantitative methods in correlating sarcopenic muscle degeneration with lower extremity function biometrics and comorbidities. PLoS One 2018;13:e0193241. doi: 10.1371/ journal.pone.0193241. eCollection 2018.

10. Vahed LK, Arianpur A, Gharedaghi M, Rezaei H. Ultrasound as a diagnostic tool in the investigation of patients with carpal tunnel syndrome. Eur J Transl Myol 2018 Apr 24;28(2):7380. doi: 10.4081/ejtm.2018.7406. eCollection 2018 Apr 24.

11. Fede C, Angelini A, Stern R, et al. Quantification of hyaluronan in human fasciae: variations with function and anatomical site. J Anat 2018;233:5526. doi: 10.1111/joa.12866. Epub 2018 Jul 24.

12. Benetazzo L, Bizzego A, De Caro R, et al. 3D reconstruction of the crural and thoracolumbar fasciae. Surg Radiol Anat 2011;33:855-62. doi: 10.1007/s00276-010-0757-7. Epub 2011 Jan 4.

13. Stecco C, Gagey O, Belloni A, et al. Anatomy of the deep fascia of the upper limb. Second part: study of innervation. Morphologie 2007;91:38-43.

14. Corey SM, Vizzard MA, Badger GJ, et al. Sensory innervation of the nonspecialized connective tissues in the low back of the rat. Cells Tissues Organs 2011;194,521-30.

15. Hoheisel U, Rosner J, Mense S. Innervation changes induced by inflammation of the rat lumbar fascia. Neuroscience 2015;300:351-59. doi: 10.10 16/j.neuroscience.2015.05.034. Epub 2015 May 21.

16. Lau WY, Blazevich AJ, Newton MJ, et al. Changes in electrical pain threshold of fascia and muscle after initial and secondary bouts of elbow flexor eccentric exercise. Eur J Appl Physiol 2015;115: 959-68. doi: 10.1007/s00421-014-3077-5. Epub 2014 Dec 18.

17. Giuriati W, Ravara B, Porzionato A, et al. Muscle spindles of the rat sternomastoid muscle. Eur J Transl Myol 2018;28:7904. doi: 10.4081/ejtm. 2018.7904. eCollection 2018 Nov 2.

18. Masiero S, Carraro U. (eds) Rehabilitation Medicine for Elderly Patients. Practical Issues in Geriatrics. Springer International Publishing AG, part of Springer Nature. doi: 10.1007/978-3-31957406-6_40.

19. Taylor MJ, Fornusek C, Ruys AJ. The duty cycle in Functional Electrical Stimulation research. Part II: Duty cycle multiplicity and domain reporting. Eur J Transl Myol 2018 Nov 7;28(4):7733. doi: 10.4081/ ejtm.2018.7733. eCollection 2018 Nov 2.

20. Taylor MJ, Fornusek C, Ruys AJ. Reporting for Duty: The duty cycle in Functional Electrical Stimulation research. Part I: Critical commentaries of the literature. Eur J Transl Myol 2018 Nov 
7;28(4):7732. doi: 10.4081/ejtm.2018.7732. eCollection 2018 Nov 2.

21. Carraro U. Exciting perspectives for Translational Myology in the Abstracts of the 2018Spring PaduaMuscleDays: Giovanni Salviati Memorial Chapter I - Foreword. Eur J Transl Myol 2018 Feb 20;28(1):7363. doi: 10.4081/ejtm.2018.7363. eCollection 2018 Jan 12.

22. Coste CA, Bergeron V, Berkelmans $\mathrm{R}$, et al. Comparison of strategies and performance of functional electrical stimulation cycling in spinal cord injury pilots for competition in the first ever CYBATHLON. Eur J Transl Myol 2017 Dec 5;27(4):7219. doi: 10.4081/ejtm.2017.7219. eCollection 2017 Dec 5

23. Sajer S. Mobility disorders and pain, interrelations that need new research concepts and advanced clinical commitments. Eur J Transl Myol 2017 Dec 5;27(4):7179. doi: 10.4081/ejtm.2017.7179. eCollection 2017 Dec 5.

24. Messina G, Martines F, Thomas E, et al. Treatment of chronic pain associated with bruxism through Myofunctional therapy. Eur J Transl Myol 2017 Jun 29;27(3):6759. doi: 10.4081/ejtm.2017.6759. eCollection 2017 Jun 27.

25. Taylor MJ, Fornusek C, Ruys AJ, et al. The Vienna FES Interview Protocol - A mixed-methods protocol to elucidate the opinions of various individuals responsible for the provision of FES exercise. Eur J Transl Myol 2017 Sep 20; 27(3):6604. doi: 10.4081/ejtm.2017.6604. eCollection 2017 Jun 27.
26. Power GA, Dalton BH, Gilmore KJ, et al. Maintaining Motor Units into Old Age: Running the Final Common Pathway. Eur J Transl Myol 2017;27(1):6597. doi: 10.4081/ejtm.2017.6597. eCollection 2017 Feb 24.

27. Coste CA, Mayr W, Bijak M, et al. FES in Europe and Beyond: Current Translational Research. Eur J Transl Myol 2016;26(4):6369. doi: 10.4081/ejtm. 2016.6369. eCollection 2016 Sep 15.

28. Lavorato M, Gupta PK, Hopkins PM, FranziniArmstrong C. Skeletal Muscle Microalterations in Patients Carrying Malignant Hyperthermia-Related Mutations of the e-c Coupling Machinery. Eur J Transl Myol 2016;26(4):6105. doi: 10.4081/ejtm. 2016.6105. eCollection 2016 Sep 15.

29. Mosole S, Carraro U, Kern H, et al. Use it or Lose It: Tonic Activity of Slow Motoneurons Promotes Their Survival and Preferentially Increases Slow Fiber-Type Groupings in Muscles of Old Lifelong Recreational Sportsmen. Eur J Transl Myol 2016 Nov 25;26(4):5972. doi: 10.4081/ejtm.2016.5972. eCollection 2016 Sep 15.

30. Laursen CB, Nielsen JF, Andersen OK, Spaich EG. Feasibility of Using Lokomat Combined with Functional Electrical Stimulation for the Rehabilitation of Foot Drop. Eur J Transl Myol 2016;26(3):6221. eCollection 2016 Jun 13.

Received for publication: January 28, 2019 Accepted for publication: February 09, 2019 